\title{
PENGARUH ORGANIZATIONAL CITIZENSHIP BEHAVIOUR, KETERLIBATAN KERJA DAN GAYA KEPEMIMPINAN TRANSFORMASIONAL TERHADAP KINERJA KARYAWAN SINOKOR MERCHANT MARINE CO., LTD.
}

\author{
Latifah \\ Suryono Efendi \\ Email: nayyarabubun@gmail.com, suryono.efendi@yahoo.com \\ Program Studi Manajemen Fakultas Ekonomi \\ Universitas Nasional
}

\begin{abstract}
ABSTRAK
Penelitian ini bertujuan untuk menguji dan menganalisis pengaruh organizational citizenship behaviour, keterlibatan kerja dan gaya kepemimpinan transformasional terhadap kinerja karyawan Sinokor Merchant Marine Co., Ltd. Penelitian ini menggunakan data primer yang diperoleh dari penyebaran kuesioner kepada 88 responden dari populasi sebanyak 700 karyawan Sinokor Merchant Marine Co., Ltd. Hasil penelitian menunjukkan bahwa organizational citizenship behaviour, keterlibatan kerja dan gaya kepemimpinan transformasional secara parsial berpengaruh positif dan signifikan terhadap kinerja karyawan Sinokor Merchant Marine Co., Ltd.
\end{abstract}

Kata kunci: Organizational citizenship behaviour, keterlibatan kerja, gaya kepemimpinan transformasional, kinerja karyawan

\section{ABSTRACT}

This study aims to test and analyze the influence of organizational citizenship behavior, work engagement and transformational leadership style on employee performance of Sinokor Merchant Marine Co., Ltd. This study used primary data that obtained from the distribution of questionnaires to 88 respondents from population with amount of 700 employees of Sinokor Merchant Marine Co., Ltd. Results of the study showed that organizational citizenship behavior, work engagement and transformational leadership style partially has positive and significant effect on employee performance Sinokor Merchant Marine Co., Ltd..

Keywords: Organizational citizenship behavior, work engagement, transformational leadership style, employee performance

\section{PENDAHULUAN}

Pertumbuhan dan perekonomian yang semakin berkembang menimbulkan munculnya kompetisi yang ketat di antara perusahaan di industri yang sejenis. Agar dapat menang di tengah persaingan yang kuat, perusahaan perlu mengelola sumber daya manusia yang dimilikinya dengan baik. Apabila sumber daya manusia dalam suatu perusahaan dikelola dengan baik, maka sumber daya manusia tersebut akan mampu mencapai kinerja yang baik serta memenuhi harapan dan ekspektasi perusahaan.

Kinerja karyawan memiliki peran yang vital dalam pencapaian visi dan tujuan perusahaan. Perusahaan dengan tingkat kinerja karyawan yang tinggi biasanya memiliki 
keunggulan kompetitif yang dapat digunakan dalam berkompetisi di pasar dan industri yang sejenis. Pentingnya peranan karyawan dalam keberhasilan suatu perusahaan memicu perusahaan untuk terus berupaya meningkatkan kinerja karyawannya. Berbagai penelitian dilakukan oleh perusahaan untuk menganalisis cara meningkatkan kinerja karyawan. Berbagai variabel dianalisis untuk mengetahui pengaruhnya terhadap kinerja karyawan. Variabel yang terbukti berpengaruh signifikan terhadap kinerja akan dieksplorasi sedemikian rupa agar perusahaan dapat secara nyata meningkatkan kinerja karyawan.

Kinerja karyawan dapat dipengaruhi oleh organizational citizenship behaviour. Menurut Organ, et al. (2006) dalam Putri dan Utami (2017), organizational citizenship behaviour adalah perilaku individu yang bebas dan tidak secara langsung diakui dalam sistem reward, tetapi dapat meningkatkan fungsi efektif perusahaan. Hasil penelitian yang dilakukan oleh Devi dan Sintaasih (2016) menemukan bahwa organizational citizenship behaviour berpengaruh positif dan signifikan tehadap kinerja karyawan. Hal tersebut menunjukkan bahwa semakin baik penerapan organizational citizenship behaviour oleh karyawan dalam suatu perusahaan, maka semakin tinggi kontribusi karyawan tersebut terhadap pekerjaan yang diberikan kepadanya, sehingga semakin tinggi pula kinerja karyawan yang bersangkutan di perusahaan tempatnya bekerja.

Berdasarkan hasil penelitian yang dilakukan oleh Kakinsale, dkk. (2015), kinerja karyawan juga dapat dipengaruhi oleh keterlibatan kerja. Hasil penelitian tersebut menunjukkan bahwa keterlibatan kerja berpengaruh positif dan signifikan terhadap kinerja karyawan. Semakin tinggi tingkat keterlibatan kerja karyawan dalam suatu perusahaan, maka semakin tinggi partisipasi aktif dari karyawan tersebut terhadap pekerjaannya, sehingga semakin tinggi pula prestasi kerja dari karyawan tersebut di tempatnya bekerja. Hal ini pada akhirnya akan meningkatkan kinerja karyawan yang bersangkutan.

Kinerja karyawan juga dapat dipengaruhi oleh gaya kepemimpinan transformasional, yaitu gaya kepemimpinan yang mampu mentransformasikan organisasi dalam menghadapi perubahan (Setiawan dan Muhith, 2013:98). Hal ini sejalan dengan hasil penelitian yang dilakukan oleh Mondiani (2012) yang menunjukkan bahwa gaya kepemimpinan transformasional berpengaruh positif dan signifikan terhadap kinerja karyawan. Semakin baik gaya kepemimpinan transformasional yang diterapkan oleh pimpinan dalam suatu perusahaan, maka semakin baik kemampuan pimpinan tersebut dalam mentransformasikan karyawannya menuju perubahan ke arah yang lebih baik, sehingga semakin baik pula kinerja karyawan yang bersangkutan di perusahaan tersebut. 
Sinokor Merchant Marine Co., Ltd. merupakan salah satu perusahaan shipping terbesar yang berpusat di Korea Selatan dan didirikan sejak tahun 1989. Sebagai perusahaan yang bergerak di bidang shipping atau jasa transportasi laut, Sinokor Merchant Marine Co., Ltd. telah melakukan pelayanan di 60 pelabuhan dalam 20 negara. Dalam pelaksanaan kegiatan operasionalnya di industri shipping, Sinokor Merchant Marine Co., Ltd. menghadapi banyak pesaing, baik yang berasal dari Korea Selatan maupun yang berasal dari luar Korea Selatan. Hal ini menuntut Sinokor Merchant Marine Co., Ltd. untuk senantiasa meningkatkan kinerjanya agar memperoleh keunggulan kompetitif dibandingkan pesaingnya di industri yang sejenis.

Dalam upaya meningkatkan kinerja karyawannya, Sinokor Merchant Marine Co., Ltd. perlu menganalisis berbagai variabel yang dapat mempengaruhi kinerja karyawannya tersebut, termasuk organizational citizenship behaviour, keterlibatan kerja dan gaya kepemimpinan transformasional. Berdasarkan latar belakang tersebut, penelitian ini dilakukan untuk menguji dan menganalisis pengaruh terhadap kinerja karyawan Sinokor Merchant Marine Co., Ltd.

\section{TINJAUAN PUSTAKA}

\section{Organizational Citizenship Behaviour (OCB)}

Organizational Citizenship Behaviour (OCB) adalah perilaku yang dilakukan oleh seorang karyawan yang melebihi kewajiban formal, namun berdampak baik karena mendukung efektivitas organisasi (Robbins, 2008). Menurut Organ, et al. (2006) dalam Putri dan Utami (2017), organizational citizenship behaviour adalah perilaku individu yang bebas dan tidak secara langsung diakui dalam sistem reward, tetapi dapat meningkatkan fungsi efektif perusahaan. Adapun menurut Aldag dan Resckhe (1997) dalam Paramita (2012), organizational citizenship behaviour adalah kontribusi yang mendalam melebihi tuntutan peran di tempat kerja dan menghasilkan kinerja yang sangat baik.

\section{Aspek-Aspek Organizational Citizenship Behaviour}

Menurut Organ, et al. (2006) dalam Putri dan Utami (2017), organizational citizenship behaviour terdiri dari lima aspek, yaitu sebagai berikut.

1. Altruism

Altruism adalah perilaku menolong rekan kerja yang sedang mengalami kesulitan, baik yang disebabkan oleh tugas perusahaan maupun yang disebabkan oleh masalh pribadi.

2. Conscientiousness 
Conscientiousness adalah perilaku karyawan yang menunjukkan usaha dan kinerja yang melebihi harapan perusahaan.

3. Sportmanship

Sportmanship adalah perilaku toleransi yang ditunjukkan oleh karyawan saat perusahaan sedang berada dalam keadaan yang kurang ideal tanpa mengajukan keberatan.

\section{Courtesy}

Courtesy adalah perilaku menjaga hubungan baik dengan rekan kerja agar terhindar dari masalah personal.

\section{Civic Virtue}

Civic virtue adalah perilaku yang mendedikasikan dirinya kepada tanggung jawab perusahan, misalnya dengan mengambil inisiatif tertentu.

\section{Keterlibatan Kerja}

Keterlibatan kerja adalah tingkat pekerjaan yang dilaksanakan oleh karyawan yang mempengaruhi harga diri dan kinerjanya (Ching-Sheue, 2015). Menurut Rivai dan Mulyadi (2012:79), keterlibatan kerja adalah ukuran sejauh mana seseorang memihak secara psikologis terhadap pekerjaannya dan menganggap kinerjanya sebagai ukuran harga dirinya. Sementara itu, Robbins (2008) mendefinisikan keterlibatan kerja sebagai derajat dimana orang dikenal dari pekerjaannya, berpartisipasi aktif di dalamnya dan menganggap prestasinya penting untuk harga diri suatu jenis pekerjaan.

\section{Karakteristik Keterlibatan Kerja}

Menurut Kanungo (1982) dalam Ansel dan Wijono (2012), keterlibatan kerja memiliki karakteristik sebagai berikut.

1. Aktif berpartisipasi dalam pekerjaan

2. Mengutamakan pekerjaan

3. Meyakini pentingnya pekerjaan bagi harga diri

\section{Gaya Kepemimpinan Transformasional}

Gaya kepemimpinan transformasional adalah gaya kepemimpinan yang mampu mentransformasikan organisasi dalam menghadapi perubahan (Setiawan dan Muhith, 2013:98). Menurut Robbins dan Judge (2007:123), gaya kepemimpinan transformasional adalah gaya kepemimpinan yang menginspirasi para pengikutnya untuk mengenyampingkan kepentingan pribadi mereka demi kebaikan organisasi dan mereka mampu memiliki pengaruh 
yang luar biasa pada diri pengikutnya. Yukl (2010:305) menyatakan bahwa gaya kepemimpinan transformasional dapat mengubah dan memotivasi para pengikut untuk lebih menyadari pentingnya hasil tugas, membujuk para pengikut untuk mementingkan kepentingan organisasi daripada kepentingan pribadi dan mengaktifkan kebutuhan para pengikut yang lebih tinggi.

\section{Kinerja}

Kinerja adalah hasil kerja yang dapat dicapai oleh seseorang atau sekelompok orang dalam suatu organisasi sesuai dengan wewenang dan tanggung jawab masing-masing dalam upaya mencapai tujuan organisasi yang bersangkutan (Sedarmayanti, 2013:260). Menurut Bastian (2006) dalam Ali (2012:212), kinerja adalah gambaran mengenai tingkat pencapaian pelaksanaan suatu kegiatan dalam mewujudkan sasaran, tujuan, misi, dan visi organisasi.

\section{Keterkaitan Antarvariabel Penelitian}

\section{Keterkaitan antara Organizational Citizenship Behaviour dan Kinerja Karyawan}

Menurut Aldag dan Resckhe (1997) dalam Paramita (2012), organizational citizenship behaviour adalah kontribusi yang mendalam melebihi tuntutan peran di tempat kerja dan menghasilkan kinerja yang sangat baik. Dalam kaitannya dengan kinerja karyawan, Putri dan Utami (2017) menemukan bahwa organizational citizenship behaviour yang diproksikan dengan altruism, conscientiouosness, sportmanship dan civic virtue mempunyai pengaruh yang positif dan signifikan terhadap kinerja karyawan.

Hasil penelitian yang dilakukan oleh Devi dan Sintaasih (2016) serta Ticoalu (2013) juga menunjukkan bahwa organizational citizenship behaviour berpengaruh positif dan signifikan tehadap kinerja karyawan. Hal tersebut dikarenakan penerapan organizational citizenship behaviour oleh karyawan dalam suatu perusahaan menunjukkan bahwa karyawan tersebut memberikan kontribusi yang tinggi terhadap pekerjaan yang diberikan kepadanya melebihi ekspektasi perusahaan. Hal ini akan meningkatkan kinerja karyawan tersebut bagi perusahaan yang bersangkutan.

$\mathrm{H}_{1}$ : Organizational citizenship behaviour berpengaruh positif dan signifikan terhadap kinerja karyawan Sinokor Merchant Marine Co., Ltd.

\section{Keterkaitan antara Keterlibatan Kerja dan Kinerja Karyawan}

Menurut Rivai dan Mulyadi (2012:79), keterlibatan kerja adalah ukuran sejauh mana seseorang memihak secara psikologis terhadap pekerjaannya dan menganggap kinerjanya 
sebagai ukuran harga dirinya. Dalam kaitannya dengan kinerja karyawan, hasil penelitian yang dilakukan oleh Safaria dan Yunastiwi (2013) serta Kakinsale, dkk. (2015) menunjukkan bahwa keterlibatan kerja berpengaruh positif dan signifikan terhadap kinerja karyawan. Semakin tinggi tingkat keterlibatan kerja karyawan dalam suatu perusahaan, maka semakin tinggi partisipasi aktif dari karyawan tersebut terhadap pekerjaannya, sehingga semakin tinggi pula prestasi kerja dari karyawan tersebut di tempatnya bekerja. Hal ini pada akhirnya akan meningkatkan kinerja karyawan yang bersangkutan.

$\mathrm{H}_{2}$ : Keterlibatan kerja berpengaruh positif dan signifikan terhadap kinerja karyawan Sinokor Merchant Marine Co., Ltd.

\section{Keterkaitan antara Gaya Kepemimpinan Transformasional terhadap Kinerja Karyawan}

Gaya kepemimpinan transformasional adalah gaya kepemimpinan yang mampu mentransformasikan organisasi dalam menghadapi perubahan (Setiawan dan Muhith, 2013:98). Menurut Robbins (2008), keberhasilan pemimpin dalam mempengaruhi karyawannya dengan visinya, menanamkan karismanya, memotivasi dan menginspirasi karyawannya, serta menstimulasi intelektual karyawannya cenderung akan mengakibatkan karyawan bekerja dengan baik dan sungguh-sungguh sehingga pada akhirnya akan meningkatkan kinerja karyawan.

Menurut Nugroho (2006) dalam Maulizar, dkk. (2012), pemimpin transformasional cenderung mengevaluasi kemampuan dan potensi setiap karyawan dalam menjalankan pekerjaannya, serta melihat probabilitas untuk memperluas tanggung jawab karyawannya di masa yang akan datang. Hal tersebut pada akhirnya akan memotivasi karyawan untuk senantiasa berupaya meningkatkan kinerjanya. Hal ini sejalan dengan hasil penelitian yang dilakukan oleh Mondiani (2012) serta Tucunan, dkk (2014) yang menunjukkan bahwa gaya kepemimpinan transformasional berpengaruh positif dan signifikan terhadap kinerja karyawan.

$\mathrm{H}_{3}$ : Gaya kepemimpinan transformasional berpengaruh positif dan signifikan terhadap kinerja karyawan Sinokor Merchant Marine Co., Ltd.

\section{Kerangka Analisis}

Kerangka analisis yang digunakan dalam penelitian ini, yaitu sebagai berikut. 


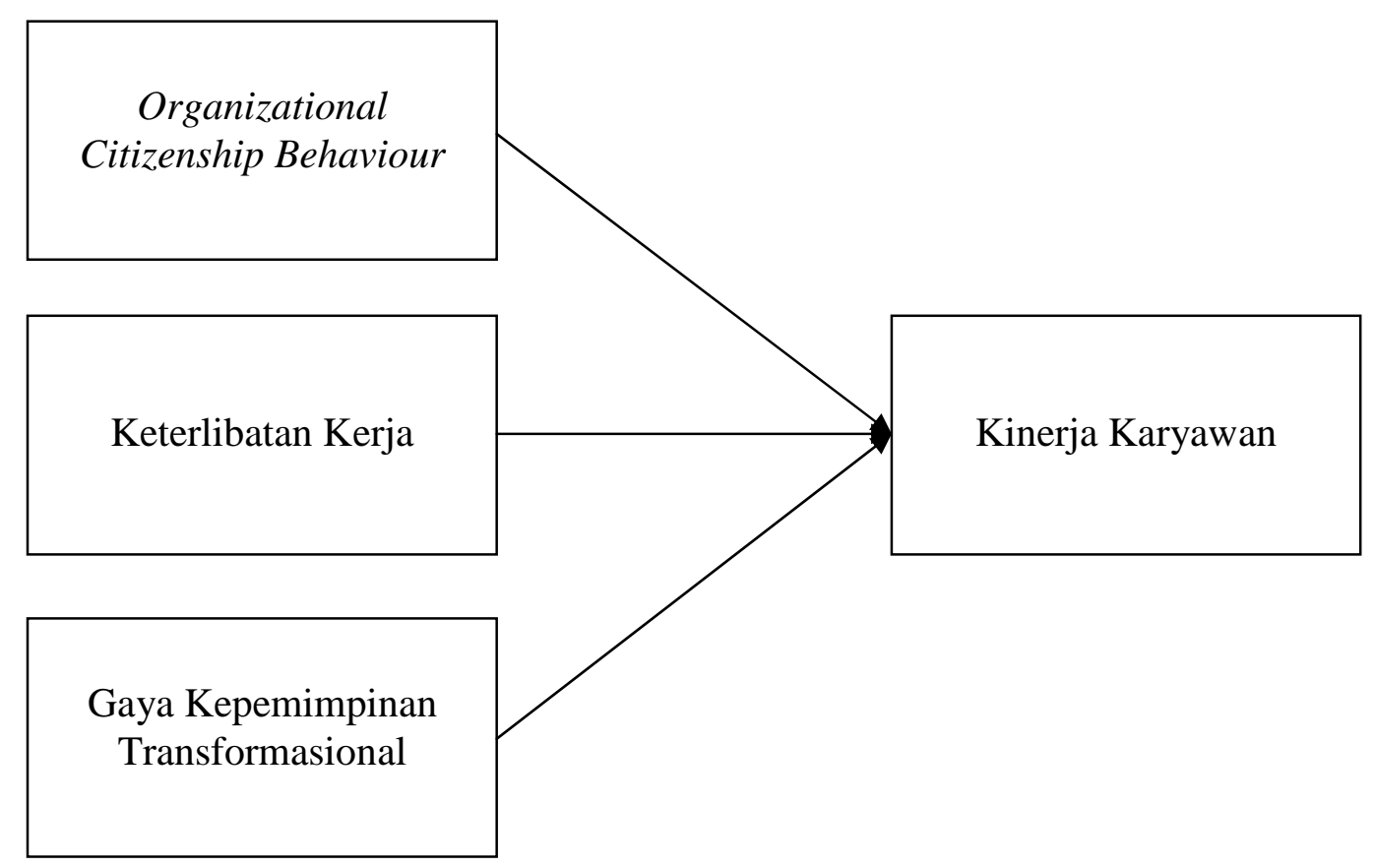

Gambar 1. Kerangka Analisis

\section{METODE PENELITIAN}

\section{Sumber dan Jenis Data}

Penelitian ini menggunakan data berjenis primer yang bersumber dari penyebaran kuesioner kepada responden.

\section{Populasi dan Sampel}

Populasi dalam penelitian ini adalah karyawan Sinokor Merchant Marine Co., Ltd yang berjumlah 700 orang. Penentuan jumlah sampel dilakukan dengan menggunakan rumus Slovin. Rumus Slovin digunakan untuk menentukan ukuran sampel dari populasi yang telah diketahui jumlahnya yaitu sebanyak 700 karyawan. Dengan standar error sebesar 10\%, jumlah sampel yang digunakan dalam penelitian ini adalah 88 responden.

\section{Definisi Operasional Variabel}

Berikut ini merupakan tabel definisi operasional variabel. 


\begin{tabular}{|c|c|c|}
\hline Variabel & Definisi Operasional & Indikator \\
\hline $\begin{array}{l}\text { Organizational } \\
\text { citizenship } \\
\text { behaviour }\end{array}$ & $\begin{array}{lrr}\text { Perilaku } & \text { karyawan } & \text { yang } \\
\text { melebihi } & \text { harapan } & \text { dan } \\
\text { tuntutan pekerjaan di tempat } \\
\text { kerja. }\end{array}$ & $\begin{array}{l}\text { 1. Sifat menolong } \\
\text { 2. Partisipasi aktif } \\
\text { 3. Disiplin } \\
\text { 4. Menghindari konflik } \\
\text { 5. Tidak suka mengeluh } \\
\text { (Sumber: Budihardjo, 2011) }\end{array}$ \\
\hline Keterlibatan kerja & $\begin{array}{l}\text { Tingkat partisipasi karyawan } \\
\text { dalam melaksanakan } \\
\text { pekerjaan di perusahaan } \\
\text { tempatnya bekerja. }\end{array}$ & $\begin{array}{l}\text { 1. Pekerjaan sebagai minat } \\
\text { utama. } \\
\text { 2. Partisipasi aktif dalam } \\
\text { Pekerjaan. } \\
\text { 3. Pekerjaan sebagai pusat } \\
\text { eksistensi } \\
\text { (Sumber: Saleh dan Hosek, 1976) }\end{array}$ \\
\hline $\begin{array}{l}\text { Gaya kepemimpinan } \\
\text { transformasional }\end{array}$ & $\begin{array}{l}\text { Gaya kepemimpinan yang } \\
\text { cenderung mengubah dan } \\
\text { mentransformasikan } \\
\text { bawahannya ke arah yang } \\
\text { lebih baik. }\end{array}$ & $\begin{array}{l}\text { 1. Pengaruh ideal/ kharismatik } \\
\text { 2. Pertimbangan Individual } \\
\text { 3. Motivasi Inspirasional } \\
\text { 4. Stimulasi Intelektual } \\
\text { (Sumber: Yukl, 2010:305) }\end{array}$ \\
\hline Kinerja & $\begin{array}{l}\text { Hasil dari pekerjaan yang } \\
\text { dilakukan oleh karyawan. }\end{array}$ & $\begin{array}{l}\text { 1. Kualitas } \\
\text { 2. Ketepatan waktu } \\
\text { 3. Kemandirian } \\
\text { 4. Komitmen kerja } \\
\text { (Sumber: Robbins, 2008:262) }\end{array}$ \\
\hline
\end{tabular}

\section{Metode Analisis}

Penelitian ini menggunakan metode analisis regresi linear berganda untuk menganalisis pengaruh organizational citizenship behaviour, keterlibatan kerja dan gaya kepemimpinan transformasional terhadap kinerja karyawan Sinokor Merchant Marine Co., Ltd.

\section{HASIL PENELITIAN}

\section{Uji Instrumen}

\section{Uji Validitas dan Uji Reliabilitas}

Berdasarkan hasil uji validitas, semua butir pernyataan dari kuesioner memiliki nilai $r$ hitung yang lebih besar daripada $\mathrm{r}$ tabel $(0,30)$. Hal tersebut menunjukkan bahwa semua butir pernyataan dari kuesioner bersifat valid. Sedangkan berdasarkan hasil uji reliabilitas, setiap variabel memiliki Cronbach Alpha dengan nilai yang lebih besar dari batas minimum sebesar 
0,7. Hal tersebut menunjukkan bahwa semua konsep pengukur dari setiap variabel dalam penelitian ini bersifat reliabel.

\section{Uji Asumsi Klasik}

\section{Uji Normalitas}

Berikut ini merupakan gambar grafik p-plot hasil uji normalitas.

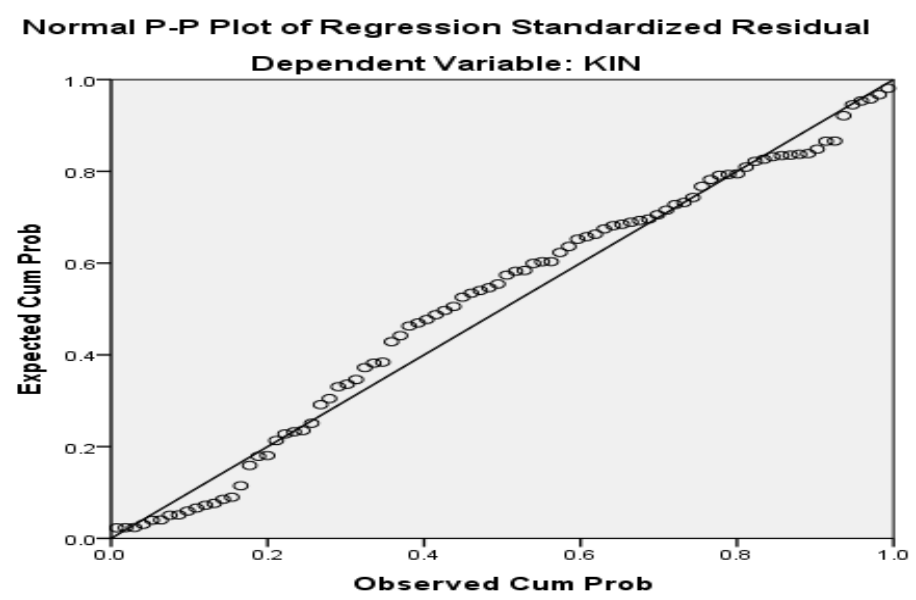

(Sumber: Data diolah, 2017)

\section{Gambar 2. Grafik Normal P-Plot}

Berdasarkan gambar di atas, titik-titik tersebar mengikuti dan mendekati arah garis diagonal sehingga dapat disimpulkan bahwa data dalam penelitian ini terdistribusi normal.

\section{Uji Autokorelasi}

Hasil uji autokorelasi menunjukkan bahwa besarnya nilai Durbin-Watson dalam model penelitian ini adalah 2,004. Dengan jumlah variabel bebas (k) sebanyak 3 dan jumlah data $(\mathrm{n})$ sebanyak 88 , diperoleh nilai $\mathrm{dL}=1,5836$ dan nilai $\mathrm{dU}=1,7243$, sehingga model dalam penelitian ini memenuhi kriteria $\mathrm{dU}<\mathrm{DW}<4$ - dU $(1,5836<2,004<2,2757)$. Hal tersebut menunjukkan bahwa tidak terjadi auto korelasi dalam model regresi ini.

\section{Uji Heteroskedastisitas}

Hasil uji heteroskedastisitas menunjukkan bahwa tidak terjadi heteroskedastisitas dalam model regresi ini karena setiap variabel memiliki nilai signifikan yang lebih besar daripada 0,05 . 


\section{Uji Multikolineritas}

Hasil uji multikolinearitas menunjukkan bahwa setiap variabel independen mempunyai nilai tolerance $>0,1$ dan $\mathrm{VIF}<10$, sehingga tidak terjadi multikolinearitas dalam model yang digunakan di penelitian ini.

\section{Analisis Regresi Linear Berganda}

Berikut ini merupakan tabel hasil uji regresi linear berganda.

Tabel 5. Hasil Uji Regresi Linear Berganda

\begin{tabular}{|l|c|c|c|}
\hline \multirow{2}{*}{ Model } & \multicolumn{2}{|c|}{$\begin{array}{c}\text { Unstandardized } \\
\text { Coefficients }\end{array}$} & $\begin{array}{c}\text { Standardized } \\
\text { Coefficients }\end{array}$ \\
\cline { 2 - 4 } & B & Std. Error & Beta \\
\hline (Constant) & 4.085 & 4.385 & \\
Organizational citizenship behaviour & 0.313 & 0.070 & 0.395 \\
Keterlibatan kerja & 0.294 & 0.081 & 0.313 \\
Gaya kepemimpinan transformasional & 0.280 & 0.103 & 0.233 \\
\hline
\end{tabular}

(Sumber: Data diolah, 2017)

Berdasarkan tabel di atas, dapat diketahui bahwa persamaan regresi linear berganda dari model yang digunakan dalam penelitian ini adalah sebagai berikut.

$$
Y=4,085+0,313 X_{1}+0,294 X_{2}+0,280 X_{3}
$$

Keterangan :

$$
\begin{array}{ll}
\mathrm{Y} & =\text { Kinerja karyawan } \\
\mathrm{X}_{1} & =\text { Organizational citizenship behaviour } \\
\mathrm{X}_{2} & =\text { Keterlibatan kerja } \\
\mathrm{X}_{3} & =\text { Gaya kepemimpinan transformasional }
\end{array}
$$

\section{Uji Kelayakan Model}

\section{Uji F}

Berdasarkan hasil uji $\mathrm{F}$, besarnya nilai $\mathrm{F}_{\text {hitung }}$ adalah 19,497 dengan nilai signifikan sebesar 0,000 yang lebih kecil daripada 0,05. Hal tersebut menunjukkan bahwa organizational citizenship behaviour, keterlibatan kerja dan gaya kepemimpinan transformasional secara bersama-sama berpengaruh positif dan signifikan terhadap kinerja karyawan. Berdasarkan hal tersebut, model yang digunakan dalam penelitian ini bersifat layak. 


\section{Koefisien Determinasi ( $\mathbf{R}^{2}$ )}

Berdasarkan hasil penelitian, besarnya koefisien determinasi dari model yang digunakan dalam penelitian ini adalah 0,389. Hal tersebut menunjukkan bahwa organizational citizenship behaviour, keterlibatan kerja dan gaya kepemimpinan transformasional memberikan kontribusi sebesar 38,9\% dalam mempengaruhi kinerja karyawan, sedangkan $61,1 \%$ sisanya dipengaruhi oleh variabel-variabel lain yang tidak dianalisis dalam penelitian ini.

\section{Pengujian Hipotesis}

Berikut ini merupakan tabel hasil pengujian hipotesis.

Tabel 7. Hasil Uji Hipotesis ( Uji t)

\begin{tabular}{|l|c|c|c|c|}
\hline \multicolumn{1}{|c|}{ Model } & T & $\begin{array}{c}\text { T } \\
\text { Tabel }\end{array}$ & Sig. & Keterangan \\
\hline Organizational citizenship behaviour & 4.474 & 1.989 & 0.000 & Positif dan signifikan \\
Keterlibatan kerja & 3.620 & 1.989 & 0.001 & Positif dan signifikan \\
Gaya kepemimpinan transformasional & 2.725 & 1.989 & 0.008 & Positif dan signifikan \\
\hline
\end{tabular}

(Sumber: Data diolah, 2017)

Berdasarkan tabel di atas, setiap variabel independen memiliki t hitung dengan nilai yang positif dan lebih besar daripada nilai $t$ tabel. Selain itu, setiap variabel independen memiliki nilai signifikan yang lebih kecil daripada $\alpha$ sebesar 0,05 . Hal tersebut menunjukkan bahwa organizational citizenship behaviour, keterlibatan kerja dan gaya kepemimpinan transformasional secara parsial berpengaruh positif dan signifikan terhadap kinerja karyawan Sinokor Merchant Marine Co., Ltd.

\section{Pembahasan}

\section{Pengaruh Organizational Citizenship Behaviour terhadap Kinerja Karyawan}

Hasil pengujian hipotesis menunjukkan bahwa organizational citizenship behaviour berpengaruh positif dan signifikan terhadap kinerja karyawan Sinokor Merchant Marine Co., Ltd. Hal ini sejalan dengan hasil penelitian yang dilakukan oleh Devi dan Sintaasih (2016) dan Ticoalu (2013). Hasil tersebut menunjukkan bahwa semakin baik penerapan organizational citizenship behaviour oleh karyawan dalam suatu perusahaan, maka semakin baik pula kinerja karyawan tersebut di perusahaan yang bersangkutan. Pada dasarnya, penerapan organizational citizenship behaviour oleh karyawan dalam suatu perusahaan mencerminkan bahwa karyawan tersebut memberikan kontribusi yang tinggi terhadap pekerjaan yang diberikan kepadanya hingga melebihi ekspektasi perusahaan itu sendiri. 
Tingginya kontribusi karyawan dalam suatu perusahaan itu sendiri akan mencerminkan tingginya kinerja karyawan tersebut di perusahaan yang bersangkutan.

\section{Pengaruh Keterlibatan Kerja terhadap Kinerja Karyawan}

Hasil pengujian hipotesis menunjukkan bahwa keterlibatan kerja berpengaruh positif dan signifikan terhadap kinerja karyawan Sinokor Merchant Marine Co., Ltd. Hal ini sejalan dengan hasil penelitian yang dilakukan oleh Safaria dan Yunastiwi (2013) serta Kakinsale, dkk. (2015). Hasil tersebut menunjukkan bahwa emakin tinggi tingkat keterlibatan kerja karyawan dalam suatu perusahaan, maka semakin tinggi partisipasi aktif dari karyawan tersebut terhadap pekerjaannya, sehingga semakin tinggi pula prestasi kerja dari karyawan tersebut di tempatnya bekerja. Hal ini pada akhirnya akan meningkatkan kinerja karyawan yang bersangkutan.

\section{Pengaruh Gaya Kepemimpinan Transformasional terhadap Kinerja Karyawan}

Hasil pengujian hipotesis menunjukkan bahwa keterlibatan kerja berpengaruh positif dan signifikan terhadap kinerja karyawan Sinokor Merchant Marine Co., Ltd. Hal ini sejalan dengan hasil penelitian yang dilakukan oleh Mondiani (2012) serta Tucunan, dkk (2014). Hasil tersebut menunjukkan bahwa semakin baik gaya kepemimpinan transformasional yang diterapkan oleh pimpinan dalam suatu perusahaan, maka semakin baik kemampuan pimpinan tersebut dalam mentransformasikan karyawannya menuju perubahan ke arah yang lebih baik, sehingga semakin baik pula kinerja karyawan yang bersangkutan di perusahaan tersebut.

Menurut Robbins (2008) keberhasilan pemimpin dalam mempengaruhi karyawannya dengan visinya, menanamkan karismanya, memotivasi dan menginspirasi karyawannya, serta menstimulasi intelektual karyawannya cenderung akan mengakibatkan karyawan bekerja dengan baik dan sungguh-sungguh sehingga pada akhirnya akan meningkatkan kinerja karyawan. Chen (2004) dalam Tucunan, dkk. (2014) menyatakan bahwa idealized influence leaders dengan budaya inovatif akan membentuk karyawan yang lebih termotivasi untuk mencapai kinerja yang diinginkan. Hal tersebut mendukung hasil penelitian ini yang menyatakan bahwa kemampuan pemimpin dalam mentransformasikan organisasi dapat mempengaruhi kinerja karyawan. Pemimpin transformasional cenderung mengevaluasi kemampuan dan potensi setiap karyawan dalam menjalankan pekerjaannya, serta melihat probabilitas untuk memperluas tanggung jawab karyawannya di masa yang akan datang 
(Nugroho, 2006). Hal tersebut pada akhirnya akan memotivasi karyawan untuk senantiasa berupaya meningkatkan kinerjanya.

\section{KESIMPULAN DAN SARAN}

\section{Kesimpulan}

Berdasarkan hasil penelitian dan pembahasan yang telah diuraikan sebelumnya, maka dapat disimpulkan bahwa organizational citizenship behaviour, keterlibatan kerja dan gaya kepemimpinan transformasional secara parsial berpengaruh positif dan signifikan terhadap kinerja karyawan Sinokor Merchant Marine Co., Ltd.

\section{Saran}

Berdasarkan hasil penelitian dan kesimpulan, berikut ini merupakan saran yang dapat dipertimbangkan oleh perusahaan dalam rangka meningkatkan kinerja karyawannya.

1. Perusahaan hendaknya dapat senantiasa mendorong karyawannya untuk menerapkan organizational citizenship behaviour dalam berperilaku di tempat kerja.

2. Perusahaan hendaknya dapat senantiasa membangun iklim kerja yang mendukung karyawan untuk memiliki tingkat keterlibatan kerja yang tinggi.

3. Pimpinan perusahaan hendaknya dapat senantiasa menerapkan gaya kepemimpinan transformasional dalam memimpin karyawannya.

\section{DAFTAR PUSTAKA}

Aldag, R. dan W. Reschke. 1997. Employee Value Added: Measuring Discretionary Effort and Its Value. Center for Organization Efectiveness.

Ali, E.M. 2012. Kepemimpinan Transformasional dalam Birokrasi Pemerintahan. Multicerdas. Jakarta.

Ansel, M.F. dan S. Wijono. 2012. Pengaruh Keterlibatan Kerja dan Kepuasan Kerja terhadap Komitmen Organisasi Polisi di Kepolisian Resor (Polres) Ende. Jurnal Psikologi. 5(2): $125-142$.

Bastian, I. 2006. Akuntansi Sektor Publik: Suatu Pengantar. Penerbit Erlangga. Jakarta.

Budihardjo, A. 2011. Organisasi Menuju Pencapaian Kinerja Optimum. Prasetya Mulya Publishing. Jakarta.

Chen, L.Y. 2004. Examining the Effect of Organization Culture and Leadership Behaviors on Organizatinal Commitment, Job Satisfaction and Job Performance at Small and Middle Sized Firms of Taiwan. The Journal of American Academy of Business. 6(4): 432-438. 
Ching-Sheue, F.U. 215. The Effect of Emotional Labor on Job Involvement in Preschool Teachers: Verifying the Mediating Effect of Psychological Capital. The Turkish Online Journal of Educational Technology. 14(3): 145-156.

Devi, N.P.A.A.K. dan D.K. Sintaasih. 2016. Organizational Citizenship Behavior, Kepemimpinan Transaksional dan Komitmen Organisasional: Pengaruhnya terhadap Kinerja Karyawan. E-Jurnal Manajemen Unud. 5(10): 6640-6669.

Kakinsale, A., A.L. Tumbel. dan G.M. Sendow. 2015. Pengaruh Keterlibatan Kerja, Lingkungan Kerja dan Kompensasi terhadap Kinerja Karyawan pada PT Bangun Wenang Beverages Manado. Jurnal EMBA. 3(1): 900-911.

Kanungo, R.N. 1982. Measurement of Job and Work Involvement. Journal of Applied Psychology. 76: 341-349.

Maulizar, S. Musnadi dan M. Yunus. 2012. Pengaruh Kepemimpina Transaksional dan Transformasional terhadap Kinerja Karyawan Bank Syariah Mandiri Cabang Banda. Jurnal Manajemen Pascasarjana Universitas Syiah Kuala. 1(1): 58-65.

Mondiani, T. 2012. Pengaruh Kepemimpinan Transformasional dan Kompensasi terhadap Kinerja Karyawan PT PLN (Persero) UPJ Semarang. Jurnal Administrasi Bisnis. 1(1).

Nugroho, R. 2006. Analisis Faktor-Faktor yang Mempengaruhi Kinerja Karyawan: Studi Empiris pada PT Bank Tabungan Negara (Persero) Cabang Bandung. Tesis. Program Studi Magister Manajemen Universitas Diponegoro. Semarang.

Organ, D.W., P.M. Podsakoff dan S.B. MacKanzie. 2006. Organizational Citizenship Behavior: Its Nature, Antecedents and Consequences. Sage Publications. London.

Paramita, P.D. 2012. Organizational Citizenship Behaviour (OCB): Aspek dari Aktivitas Individual dalam Bekerja. Majalah Ilmiah Universitas Pandanaran. 10(24).

Putri, Y.D. dan H.N. Utami. 2017. Pengaruh Organizational Citizenship Behavior terhadap Kinerja: Studi pada Tenaga Perawat Ruang Rawat Inap Rumah Sakit Baptis Batu. Jurnal Administrasi Bisnis. 46(1): 27-34.

Rivai, V. dan D. Mulyadi. 2012. Kepemimpinan dan Perilaku Organisasi. Raja Grafindo Persada. Jakarta.

Robbins, S,P. 2008. Organisational Behaviour. Pearson Education Australia. Melbourne.

Robbins, S.P. dan T. A. Judge. 2007. Organizational Behaviour. $12^{\text {th }}$ Ed. Pearson Education. New Jersey.

Safaria, S. dan A.S. Yunastiwi. 2013. Pengaruh Keterlibatan Kerja Terhadap Kinerja Pegawai: Studi pada PT Seascape Surveys Indonesia. E-Jurnal Ilmu dan Bisnis. 1(1): $1-17$.

Saleh, S.D. dan J. Hosek. 1976. Job Involvement: Concepts and Measurements. Academy of Management Journal. 19(2): 213-224. 
Sedarmayanti. 2013. Manajemen Sumber Daya Manusia Reformasi Birokrasi dan Manajemen PNS. Refika Aditama. Bandung.

Setiawan, B.A. dan A. Muhith. 2013. Transformational Leadership: Ilustrasi di Bidang Organisasi Pendidikan. Rajawali Press. Jakarta.

Ticoalu, L.K. 2013. Organizational Citizenship Behaviour (OCB) dan Komitmen Organisasi Pengaruhnya terhadap Kinerja Karyawan: Studi pada PT Bank Tabungan Pensiunan Nasional Cabang Manado). Jurnal EMBA. 1(4): 782-790.

Tucunan, R.J.A., W.G. Supartha dan I.G. Riana. 2014. Pengaruh Kepemimpinan Transformasional terhadap Motivasi dan Kinerja Karyawan: Studi Kasus pada PT Pandawa. E-Jurnal Ekonomi dan Bisnis. 3(9).

Yukl, G.A. 2010. Leadership in Organizations. Pearson Prentice Hall. New Jersey. Terjemahan B. Suprianto. Indeks. Jakarta. 